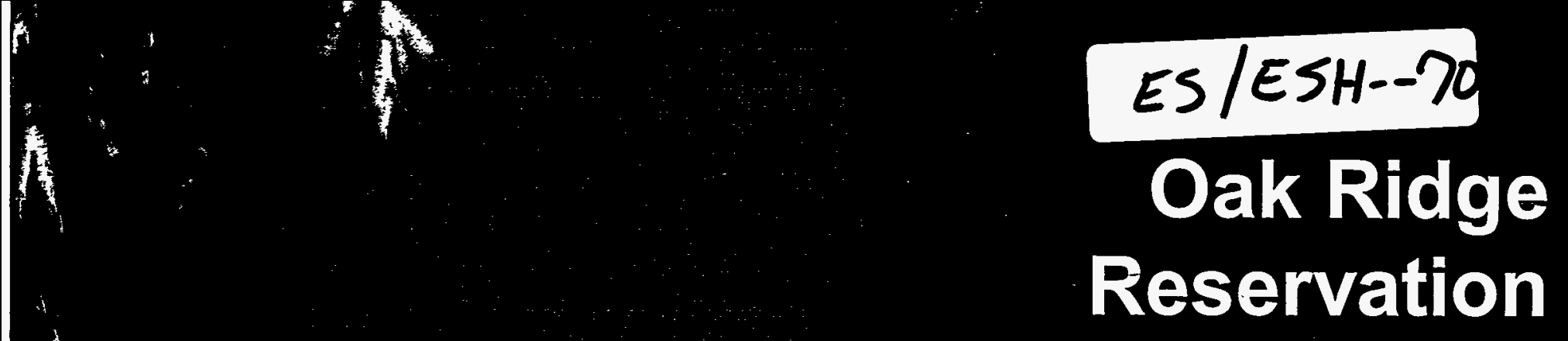

\author{
Annual Site \\ Environmental \\ Report Summary \\ for 1995
}

$1 k^{2}$

ist 
This report has been reproduced directly from the best available copy. Available to DOE and DOE contractors from the Office of Scientific and Technical Information, P.O. Box 62, Oak Ridge, TN 37831; prices available from (423) 576-8401. Available to the public from the National Technical Information Service, U.S. Department of Commerce, 5285 Port Royal Rd., Springfield, VA 22161.

This report was prepared as an account of work sponsored by an agency of the United States Government. Neither the United States nor any agency thereof, nor any of their employees, makes any warranty, express or implied, or assumes any legal liability or responsibility for the accuracy, completeness, or usefulness of any information, apparatus, product, or process disclosed, or represents that its use would not infringe privately owned rights. Reference herein to any specific commercial product, process, or service by trade name, trademark, manufacturer, or otherwise, does not necessarily constitute or imply its endorsement, recommendation, or favoring by the United States Government or any agency thereof. The views and opinions of authors expressed herein do not necessarily state or reflect those of the United States Government or any agency thereof.

On the cover: A great egret (ardea alba) perches beside the Swan Pond at Oak Ridge National Laboratory. A close relative of the great blue heron, the great egret was hunted nearly to extinction at the turn of the century because its plumage had become a popular adornment for women's hats. Once an uncommon visitor to East Tennessee, the great egret has expanded its breeding range north from the coastal plain. Lakes impounded by Tennessee Valley Authority dam-building projects, such as Melton Lake adjacent to the Oak Ridge Reservation, provide new habitat in which the egrets can breed.

(ORNL PHOTO 3638-96) 


\section{Oak Ridge Reservation Annual Site Environmental Report Summary for 1995}

December 1996

This document was prepared by Oak Ridge National Laboratory, P.O. Box 2008, Oak Ridge, TN 37831-6285, managed by Lockheed Martin Energy Research Corp. for the U.S. Department of Energy under Contract No. DE-AC05-96OR22464, and by the Oak Ridge Y-12 Plant and the Oak Ridge K-25 Site, P.O. Box 2008, Oak Ridge, TN 37831-6285, Managed by Lockheed Martin Energy Systems, Inc., for the U.S. Department of Energy under Contract No. DE-AC05-84OR21400. 


\section{DISCLAIMER}

Portions of this document may be illegible electronic image products. Images are produced from the best available original document. 


\section{Preface}

The U.S. Department of Energy (DOE) requires an annual site environmental report from each of the sites operating under its authority. The reports present the results from the various environmental monitoring and surveillance programs carried out during the year. In addition to meeting the DOE requirement, the reports also document compliance with various state and federal laws and regulations.

The Oak Ridge Reservation Annual Site Environmental Report for 1995 (ES/ESH-69) was published to fulfill those requirements for the Oak Ridge Reservation (ORR) for calendar year 1995. The report is based on thousands of environmental samples collected on and around the ORR and analyzed during the year. The data on which the report is based are published in Environmental Monitoring and Surveillance on the Oak Ridge Reservation: 1995 Data (ES/ESH-71). Both documents are highly detailed. This summary report (ES/ESH-70) is meant for readers who are interested in the monitoring results but who do not need to review the details.

The ORR report and summary are public documents, distributed to government regulators, scientists, engineers, business people, special interest groups, and members of the public at large. They are available in public reading rooms and libraries. In addition, all three documents are available on request from

ORNL Laboratory Records

P.O. Box 2008

Oak Ridge, TN 37831-6285.

For on-line versions of the report and summary, visit the following World-Wide Web site: http://www.ornl.gov/Env_Rpt/aser95/aser.htm. Some of the 1995 data is available on the Oak Ridge Environmental Information System (OREIS) to those who have a Lockheed Martin Energy Systems user identification. For more information, visit the OREIS home page on the World-Wide Web (http://www-internal.ornl.gov/ oreis/oreishome.html).

The authors encourage comments on these reports so that the needs of our readers can be better addressed. Please direct your comments to

ASER Editor

P.O. Box 2008

Oak Ridge, TN 37831-6144

(e-mail wqk@ornl.gov). 


\section{About the Oak Ridge Reservation}

The U.S. Department of Energy (DOE) currently oversees activities on the Oak Ridge Reservation (ORR), which is the property of the U.S. government. The reservation is located in Anderson and Roane counties in eastern Tennessee, on about 34,700 acres within the city of Oak Ridge (Fig. 1). About 880,000 people live within a 50-mile radius of the reservation.

The ORR was established in the early 1940s as part of the Manhattan Project. Uranium was enriched and weapon components were fabricated in facilities on the reservation. Many production activities were curtailed during the 1980 s.

The reservation comprises three major facilities: the Oak Ridge Y-12 Plant, Oak Ridge National Laboratory (ORNL), and the Oak Ridge K-25 Site (Figs. 2, 3, and 4). It is home to the Graphite Reactor, a national historical landmark, and to a 12,375-acre national environmental research park, one of seven established across the nation by DOE.

The reservation is a government-owned, contractor-operated facility. It was operated by Martin Marietta Energy Systems, Inc., from April 1984 until March 1995, at which time the Martin Marietta Corporation merged with Lockheed. The Lockheed Martin Corporation subsequently organized into several business sectors, two of which currently manage the major Oak Ridge facilities. Lockheed Martin Energy Systems manages the Y-12 Plant and the K-25 Site, and Lockheed Martin Energy Research Corporation manages ORNL.

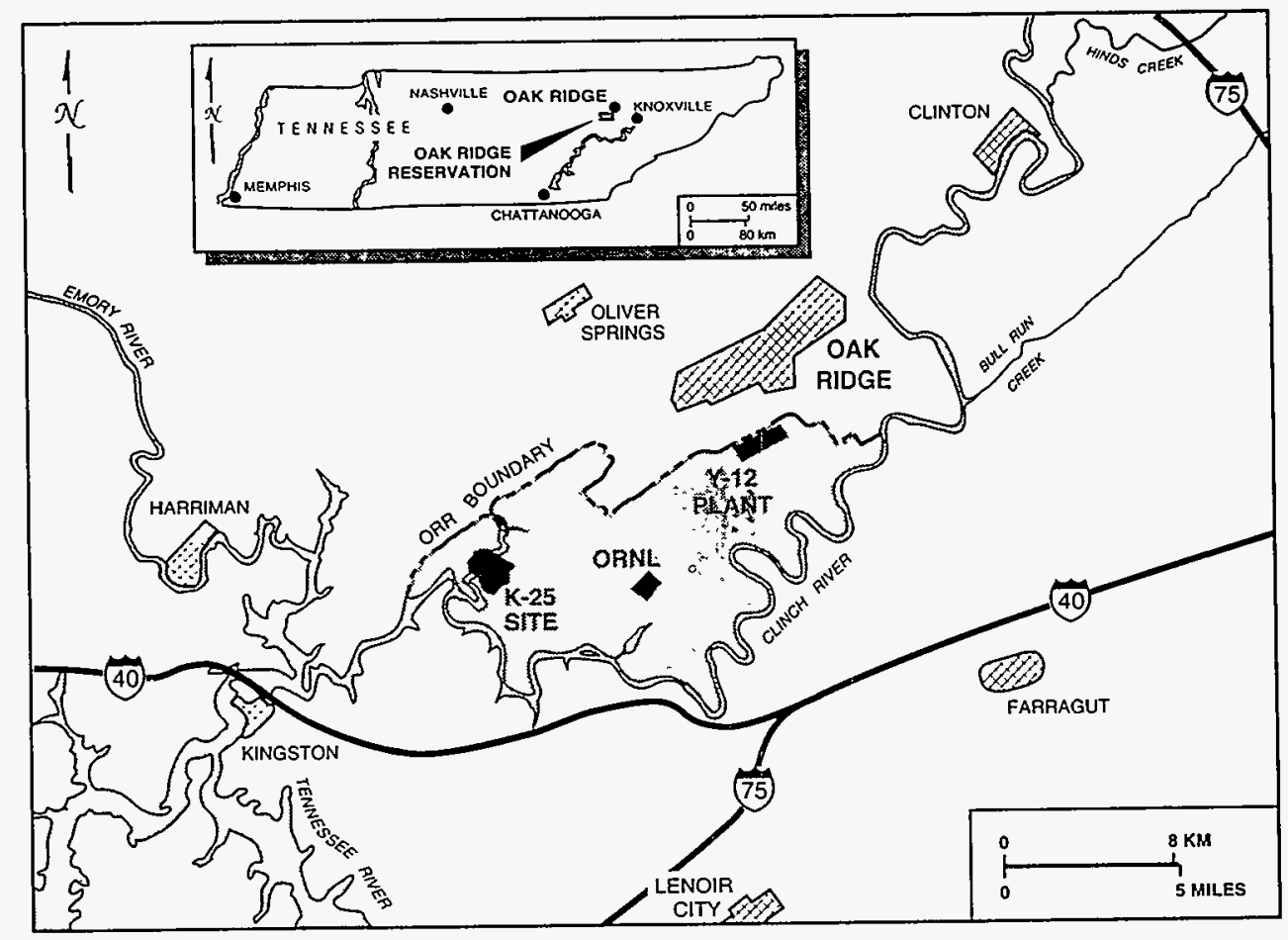

Fig. 1. The Oak Ridge Reservation and surroundings. 
The Oak Ridge Institute for Science and Education (ORISE) has stewardship responsibility for two parcels on the reservation: the Scarboro Operations Site and the Freels Bend Tract. ORISE is managed for DOE by Oak Ridge Associated Universities (ORAU), a nonprofit consortium of 82 colleges and universities (Fig. 5).

\section{ROLE OF THE OAK RIDGE RESERVATION}

The ORR's role has evolved over the years and continues to adapt to meet the changing defense, energy, and environmental needs of the United States. Currently, the reservation facilities are involved in areas such as environmental technology development, materials research and development, technology transfer, and radioisotope production.

In addition to support of the war effort, subsequent research, development, and production activities have produced hazardous wastes, and continue to do so today. For that reason, much of the current work on the reservation involves environmental monitoring, surveillance, waste management, and environmental restoration to deal with wastes from ongoing projects and from the legacy of the past. In addition, DOE orders and federal and state regulations require documented environmental monitoring for these facilities, the results of which are published in annual site environmental reports.

\section{RESERVATION ECOLOGY}

When the ORR was acquired by the federal government in 1942 for the Manhattan Project, it consisted of

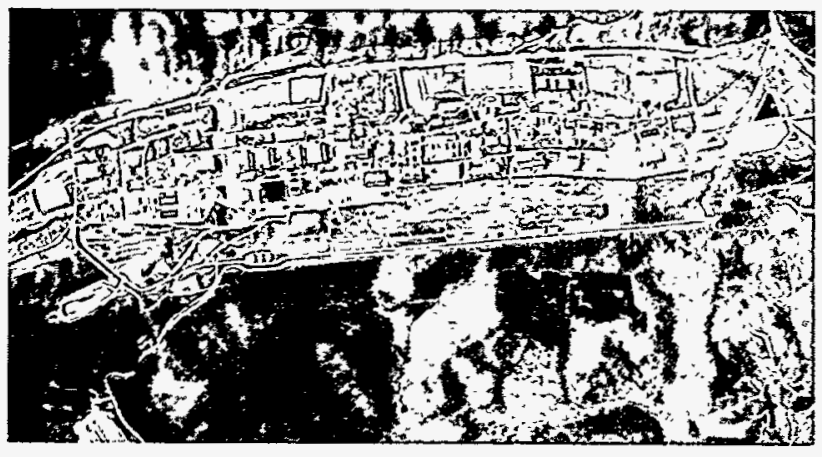

Fig. 2. The Oak Ridge Y-12 Plant.

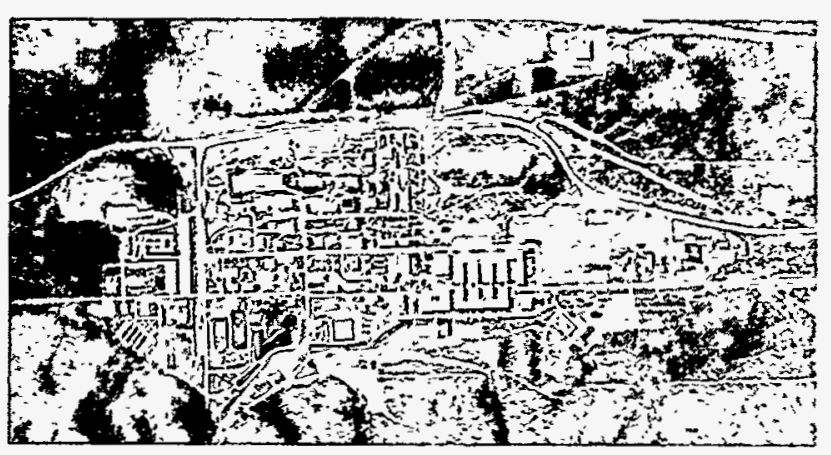

Fig. 3. Oak Ridge National Laboratory.

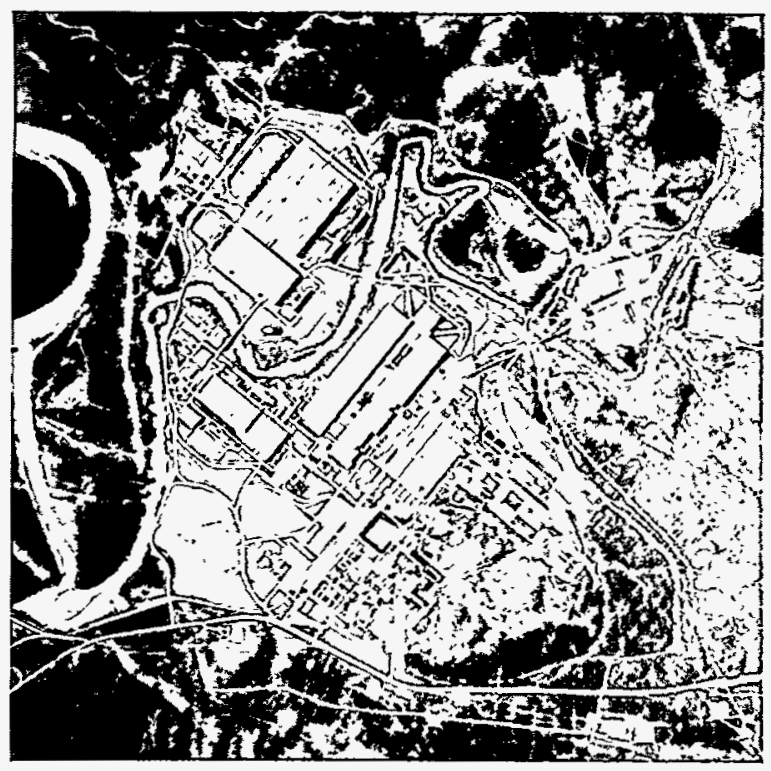

Fig. 4. The Oak Ridge K-25 Site. 


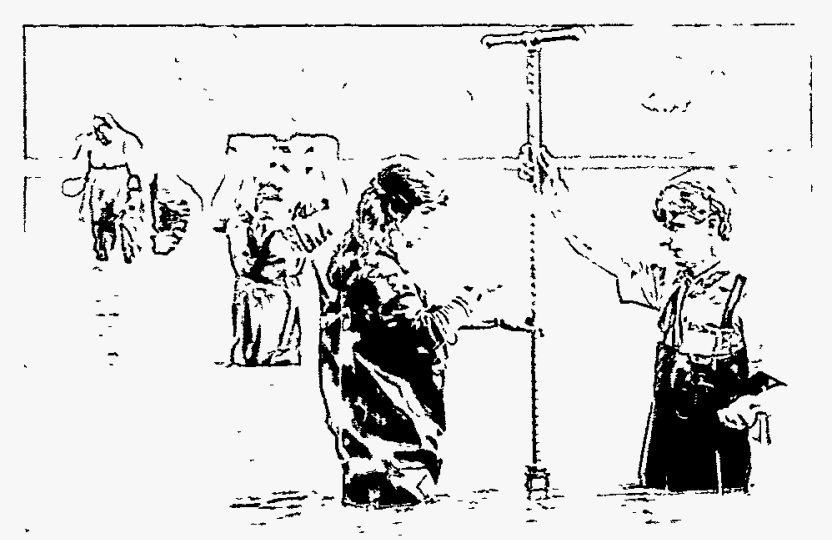

Fig. 5. Students learn sediment-sampling techniques as part of the Environmental Monitoring course offered by the ORISE Education and Training Division's Professional Training Program (PTP). More than 25,000 individuals have attended PTP courses in Oak Ridge since the program's inception in 1948. about 1000 individual tracts of land, primarily farmsteads. This land was a patchwork of forests, wooded pastures, and fields.

Aerial photographs taken in the mid-1920s and late 1930s show that about half of the area was cleared. Some clearings for orchards and pastures were on upper slopes, rocky areas, and ridge tops; tillage crops were mostly restricted to lower slopes and bottomlands. Agricultural practices of the time resulted in severe erosion on most slopes. Erosion gullies are still evident in some areas. Except on very steep slopes, most of the forest was cut for timber but was not always cleared. Many partially cut forest areas were used as rough pasture.

The ORR was selected to be a Biosphere Reserve in 1988 and is a unit of the Southern Appalachian Biosphere Reserve. It plays an important role as the only representative of the ridge-and-valley physiographic province in the international United Nations Educational, Scientific, and Cultural Organization (UNESCO) Man and Biosphere Program.

On an area basis, the reservation is richer in federally protected plants than is the Great Smoky Mountains National Park. In fact, the ORR has about four times as many listed species per unit area as the Great Smoky Mountains National Park-an impressive return in species preservation per investment in area. This richness is just one of the reasons that the reservation is of great regional and national importance in conserving biological diversity.

Forests, primarily oak-hickory, pine-hardwood, or pine with oak-hickory, currently cover about $75 \%$ of the reservation. About 500 acres of wetlands are also found throughout the reservation. More than 1000 different species of vascular plants grow on the reservation. By comparison, 1300 known plant species have been observed in the Great Smoky Mountains National Park. Twenty different species of rare plants occur on the reservation; all of them are on the state's rare plant list, and four of them are under consideration for federal listing.

In addition, the ORR supports a wide variety of animal species, including 60 reptilian and amphibian species; 63 fish species; more than 120 species of terrestrial birds; 32 species of waterfowl, wading birds, and shorebirds; and about 40 mammalian species. The ORR also supports animal life listed as threatened by the state of Tennessee (Fig. 6). Habitats supporting the greatest number of species are those dominated by hardwood forests and wetlands.

\section{OUR OPERATIONS ARE GOVERNED BY STATE AND FEDERAL LAWS AND REGULATIONS}

It is ORR environmental policy to conduct its operations in a safe and environmentally sound manner and to comply fully with all environmental rules and regulations. Growing public awareness and environmental concern in recent years have prompted Congress to 
pass increasingly stringent laws aimed at protecting the environment. In keeping with our policy, we continue to work closely with the regulating agencies to minimize the effect of our operations on public health and the environment and to ensure continued compliance with regulations.

The U.S. Environmental Protection Agency (EPA) and the Tennessee Department of Environment and Conservation (TDEC) are the principal regulators of ORR activities. These agencies issue permits, review compliance reports, participate in joint monitoring programs, inspect facilities and operations, and oversee compliance with applicable regulations.

The following are a few of the numerous federal and state laws with which ORR facilities must comply:

- Clean Air Act

- Clean Water Act

- Comprehensive Environmental Response, Compensation, and Liability Act (CERCLA)

- Emergency Planning and Community Right-To-Know Act

- Endangered Species Act

- Federal Facilities Compliance Act

- Federal Insecticide, Fungicide, and Rodenticide Act

- National Environmental Policy Act

- National Historic Preservation Act

- Resource Conservation and Recovery Act

- Safe Drinking Water Act

- Toxic Substances Control Act

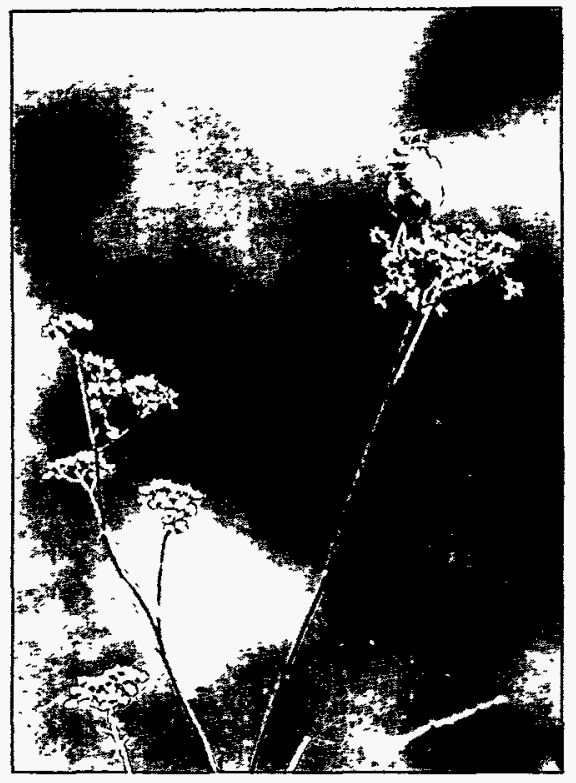

Fig. 6. This grasshopper sparrow, listed as threatened by the state of Tennessee, was spotted in the Freels Bend area of the ORR.

\section{ENVIRONMENTAL MANAGEMENT PROGRAM}

The Oak Ridge Environmental Management Program has four primary components. Environmental restoration studies environmental contamination and proposes cleanup solutions. Decontamination and decommissioning removes bulk contaminants and contaminated equipment from process buildings no longer in use. Waste management treats, stores, and disposes of waste generated from DOE operations and cleanup work. Technology development creates new technologies or modifies existing technologies to solve environmental problems. Public involvement in decision making is also an integral part of the Environmental Management Program.

For nearly half a century, one of the primary missions of DOE and its predecessor agencies was the production of nuclear weapons for the nation's defense. Production of materials for nuclear weapons, which began on the ORR in 1943, as part of the secret World War II Manhattan Project, also produced radioactive and hazardous wastes. In 1989 the reservation was placed on EPA's National Priorities List (NPL), which names waste sites across the country most in need of cleanup. 
Once the reservation was added to the NPL, cleanup became subject to the process specified in CERCLA, more commonly known as Superfund. This law requires federal agencies and private-sector companies to investigate and remedy abandoned or uncontrolled hazardous waste sites where a release has occurred or may occur. It also requires public involvement to ensure that citizens are informed of and are involved in making cleanup decisions.

In 1990 DOE-HQ established the Office of Environmental Management, making DOE-ORO responsible for cleanup of the reservation, with Martin Marietta Energy Systems serving as its managing and operating contractor. The following sections highlight some of the environmental management projects that were addressed in 1995.

\section{Environmental Resioration}

\section{K-25 Powerhouse Razed}

On September 9, 1995, The K-25 Powerhouse was demolished. Explosives were used to implode the steel structure after most of the brick and masonry walls had been removed. The facility was built in 1945 in support of the Manhattan Project and later was used for offices, laboratories, and storage. The Powerhouse demolition was part of DOE's

Environmental Restoration Incentive Project program, a new contracting method that promotes faster, more cost-effective cleanups without compromising safety (Fig. 7). The scope of this project included decontamination and demolition of 14 of the 22 structures located in the Powerhouse Area.

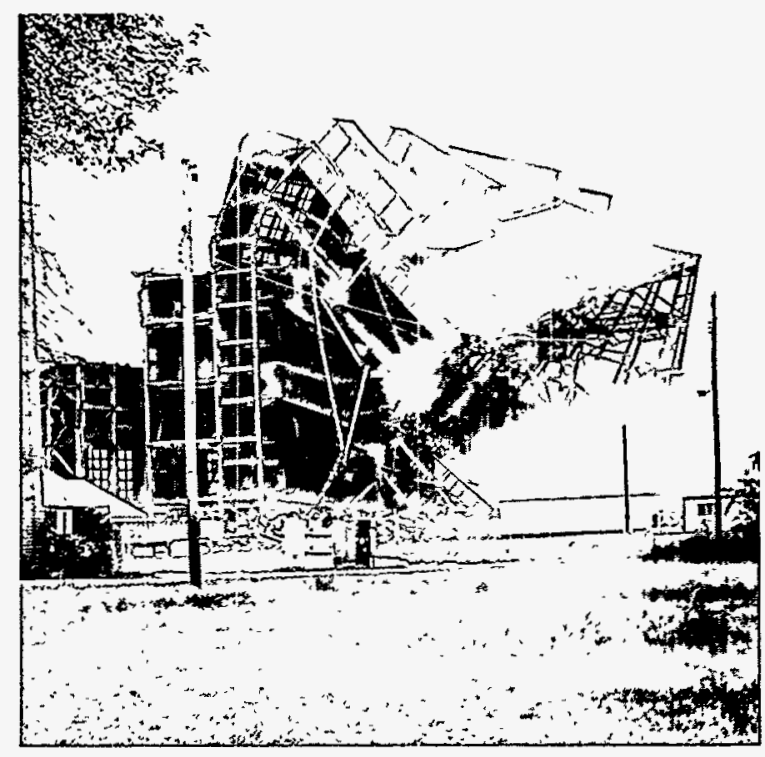

Fig. 7. The framework of the K-25 Powerhouse was demolished as part of DOE's Environmental Restoration Incentive Project program.

\section{Lower Watts Bar Reservoir Investigated}

In 1995 DOE completed an environmental investigation of Lower Watts Bar Reservoir downstream from Kingston (Fig. 8). Copies of DOE's findings were made available to the public, and stakeholders meetings were held in Oak Ridge, Kingston, and Spring City. The public had the opportunity to comment on the DOE findings between March 24 and April 28, 1995. Results of the survey showed that risks from contaminants in the reservoir are very low. Therefore, DOE recommended that no action be taken to remove the contaminants

Polychlorinated biphenyls (PCBs) and radioactive cesium are the contaminants of greatest concern in the reservoir. PCBs are cancer-causing industrial chemicals that accumulate in the flesh of fish. Their presence in Lower Watts Bar Reservoir can be attributed in part to DOE activities, although their use was once widespread, and they are also found in waters upstream of the ORR. Most of the cesium contamination resulted from DOE activities that took place 40 years ago. Small but detectable amounts are buried in the deep-water sediment of the reservoir. 


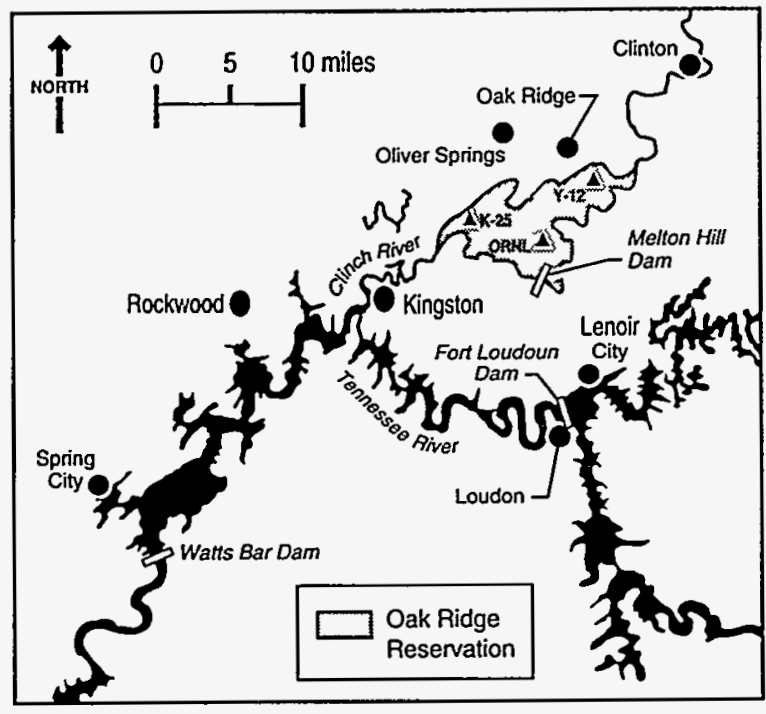

Fig. 8. The Clinch River flows past the ORR en route to Kingston, where it merges with the Tennessee River. The Lower Watts Bar Reservoir extends from Kingston south to Watts Bar Dam, south of Spring City.
DOE and its regulators (EPA and TDEC) have signed the Lower Watts Bar Reservoir Record of Decision. The record of decision includes comments received during the public comment period and calls for institutional controls, such as fishing advisories and control of dredging activities, to limit exposure to contaminants in fish and sediments. DOE will continue monitoring conditions in the reservoir for at least another 5 years, at which time DOE, EPA, and TDEC will determine whether further monitoring is needed.

\section{DOE Submits Record of Decision for Remediation of Lower East Fork Poplar Creek}

On June 1, 1995, DOE delivered its Record of Decision for Lower East Fork Poplar Creek to EPA and TDEC for approval. DOE also held a public meeting on June 8 to explain it to the public. The record of decision documents DOE's plan for the removal of mercury contamination from floodplain soil along the creek (Fig. 9). The contamination was released inadvertently into the creek from the Y-12 Plant during the 1950 s, where for many years mercury was used in production processes.

The planned remediation involves removal of contaminated soil until the level of mercury (measured in parts per million) is reduced and is no longer a threat to human health. To determine a safe level, DOE considered the types of mercury compounds present as well as the quantity. The threat posed by mercury to human health, and the health of other organisms, depends on how readily the mercury is taken into the body; for example,

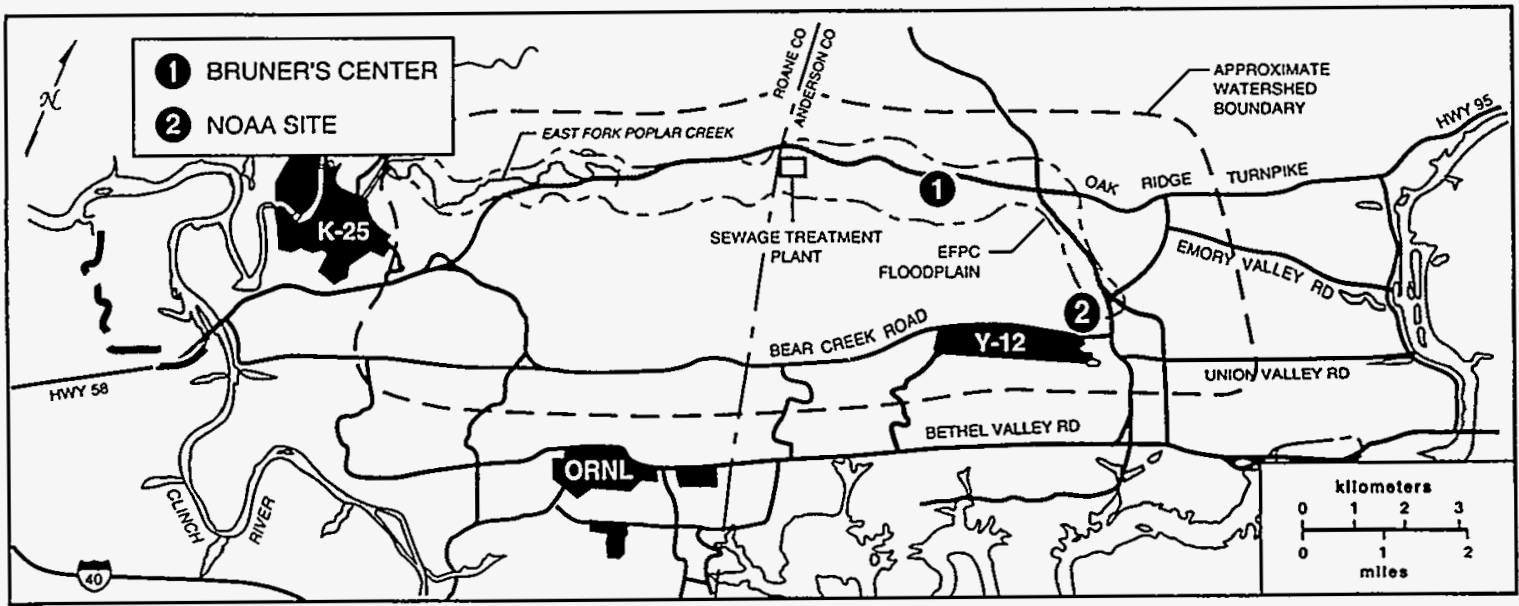

Fig. 9. The Record of Decision for Lower East Fork Poplar Creek calls for excavating the Bruner's Center site along the Oak Ridge Turnpike and the NOAA site along Illinois Avenue. 
some forms of mercury, such the elemental metal and mercuric sulfide, are less easily absorbed than mercuric chloride. By identifying the amounts and types of mercury present, DOE was able to determine a "percent bioavailablity factor," from which it could estimate a safe part-per-million concentration for the Lower East Fork Poplar Creek floodplain soil. Its findings were corroborated by EPA, TDEC, and the Agency for Toxic Substances and Disease Registry (ATSDR), which is part of the Centers for Disease Control.

DOE's planning was also tempered by public opinion. On January 26, 1995, DOE held a public meeting to announce a proposed plan for removal of the mercury. The plan was the result of a remedial investigation that had begun in 1990. DOE received 90 responses from the public, 50 at the meeting and 40 more during the comment period, which lasted until February 22. It was the most responses ever generated from a proposed remedial action in Oak Ridge. Many of the comments expressed concerns that the proposed excavations would harm the floodplain ecology, which in spite of the mercury, is thriving. Following the announcement of a revised cleanup level, DOE held another comment period, from June 14 to July 14.

Actions to be taken include the removal of all floodplain soil containing mercury concentrations above $400 \mathrm{ppm}$, thus reducing the threat to human health while minimizing the impact on the local ecology. The creek will continue to be monitored to determine the effectiveness of the project. The soil will be taken to a permitted landfill on the Y-12 Plant, and the excavated sites will be back-filled with clean soil. At a cost of about $\$ 30$ million, the project will allow unrestricted future land use. All documentation, including public comments and the ATSDR report, pertaining to the Lower East Fork Poplar Creek Floodplain remediation project is available at the DOE Information Resource Center, 105 Broadway Avenue, Oak Ridge.

\section{Decontamination and Decommissioning}

\section{Variable Dose Rate Irradiation Facility Dismantled}

The Variable Dose Rate Irradiation Facility (VDRIF), located on the ORR, has been dismantled. During the 1960s and 1970s, VDRIF had served as state-of-the-art radiation-exposure research facility. It contributed significantly to experiments in radiobotany, pathology, soil chemistry and plant nutrition, genetics, and animal physiology. In 1995 its cobalt-60 sources were removed, thus ending the long useful service of VDRIF.

Research into the effects of radioactive fallout began in Oak Ridge in 1948, following the weapons testing at Alamogordo, New Mexico. The Atomic Energy Commission set aside a portion of the ORR as an agricultural research station to be operated jointly with the University of Tennessee. Its purpose was to study responses of plants and animals to external radiation, uses of radioisotopes in agricultural research, and transport of radionuclides in food chains. During the 1950s the open-air Low Dose Irradiation Facility was constructed to study the effects of whole-body gamma radiation on large animals.

The desire to conduct experiments at higher dose rates led to the building of VDRIF. Funding for construction was authorized by the Atomic Energy Commission. ORNL, the Y-12 Plant, and the University of Tennessee collaborated to supply the design and materials.

The VDRIF is an enclosed structure containing an entrance maze, a control room, and an irradiation room. Each of the six cobalt- 60 radiation sources contained 3631 -cm-diam. wafers within stainless steel, lead-shielded tubes. The activity of the wafers increased exponentially from top to bottom to provide variable dose rates, and each source could be raised or lowered independently of the others from shielded wells. In June 1967 the activity 
of each source, $452 \mathrm{Tbq}(4.52 \mathrm{E}+14 \mathrm{~Bq}$ or $1.2 \mathrm{E}+16 \mathrm{pCi})$, contributed to an initial maximum exposure of about $70 \mathrm{R} / \mathrm{min}$ at the exposure stations.

The Agricultural Research Laboratory (renamed the "Comparative Animal Research Laboratory" in 1975) became the responsibility of ORAU in 1981. The VDRIF sources were last used in May 1984; the sources were sealed and the lifting mechanisms were removed in 1991. In 1995 a company under contract to ORAU on behalf of DOE transported the sources to California for recycling. The VDRIF structure is currently vacant and is available for other uses.

\section{Waste Management}

\section{TDEC Issues an Order for Mixed-Waste Treatment and Storage}

In September 1995 the commissioner of TDEC issued an order to DOE that specifies a schedule for the treatment and disposal of mixed waste originating from the three ORR sites. In early April 1995, DOE submitted to TDEC a proposed treatment plan for all mixed wastes on the ORR. The development of the plan encouraged stakeholder involvement, which in addition to general stakeholder meetings included three workshops for local individuals interested in waste treatment. The state order modifies the proposed site treatment plan.

Mixed waste is a mixture of hazardous waste (chemicals) and low-level or transuranic radioactive waste components. $D O E$ was required to submit a mixed-waste treatment plan under RCRA as amended by the Federal Facilities Compliance Act of 1992. The Act requires that hazardous components of mixed waste be treated before disposal.

The final order details a timetable for treatment of the wastes, includes schedules for additional characterization of some wastes when it is required to support planning for treatment, and takes into account funding availability. It will be reviewed annually to consider changing technologies and funding levels. The order is available in the DOE Public Reading Room at 55 Jefferson Circle, off the turnpike in Oak Ridge.

\section{Envirocare Shipments Continue}

Shipments are continuing from the K-25 Site to Envirocare of Utah, Inc. Since August of 1994 more than 20,592 drums (264 box cars) have been shipped to the Envirocare facility, located 80 miles (about $129 \mathrm{~km}$ ) west of Salt Lake City. Wastes shipped from the $\mathrm{K}-25$ Site include material dredged from two ponds as well as ash from the TSCA Incinerator.

Envirocare is the only commercial facility in the United States licensed to dispose of mixed waste once it has been treated to stabilize the hazardous components. After the box cars arrive at Envirocare, the drums are unloaded, are tested to ensure that they meet waste acceptance criteria, and are placed in a lined disposal cell. When the cell is filled, steel box lids are placed around the drums, forming a boundary (Fig. 10). Clean concrete is then poured over the drums to fill void spaces between them. Once filled completely, the cell is capped with clean soil. 


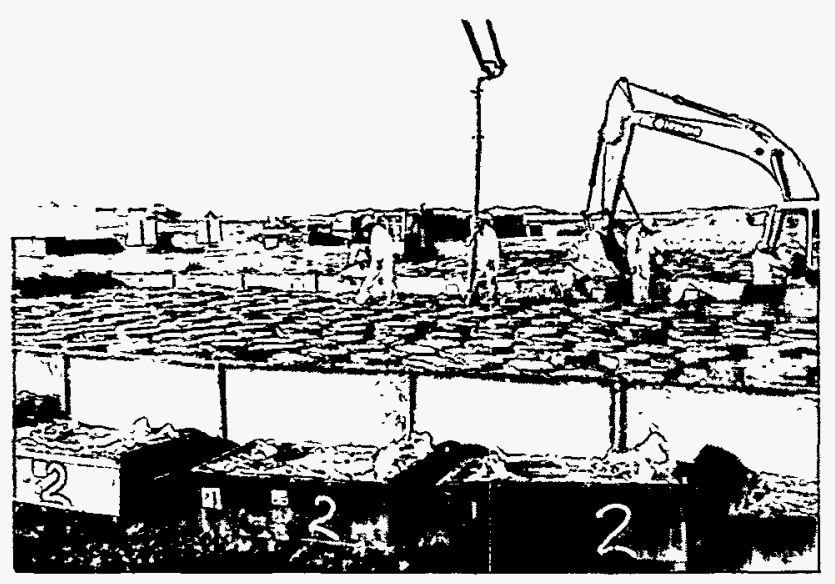

Fig. 10. Workers at Envirocare of Utah, Inc., prepare to pour clean concrete in the void spaces between drums, to seal the drums in the lined disposal cell. Once the drums have been sealed in the lined disposal cell with clean concrete, the area is capped with clean soil.

\section{Technology Development}

\section{TRANSCOMI Tracks Waste Shipments}

The U.S. Transportation Command (TRANSCOM) is part of DOE's Transportation Information Network, which uses a satellite positioning and reporting system to track highway shipments of waste and spent nuclear fuel. After vehicle information is transmitted to a satellite receiving station, it is relayed to the TRANSCOM Control Center in Oak Ridge, located at 3 Main Street. Authorized users can gain access to the information from their personal computers.

\section{Interim Waste Management Facility Refines Tumulus Disposal Technique}

At the ORNL Interim Waste Management Facility (IWMF) DOE applies "tumulus" disposal technology to ensure that low-level radioactive waste (LLW) stays isolated from the environment. Developed by the French nuclear industry, tumulus disposal involves placing compacted LLW in metal boxes, sealing the boxes, and placing them inside concrete vaults. The vaults are stacked three-high on an engineered concrete pad that has been reinforced with layers of sand and gravel and with plastic and fabric liners. Impervious liners and soil are placed over completed stacks, making an earthen mound that resembles the ancient burial sites from which the technique gets its name.

Tumulus disposal began at ORNL in 1988, when two pads were installed at Solid Waste Storage Area 6. The first two pads were used until 1992; they are currently sealed and covered. The first IWMF pad was built in 1991. The design was modified, based on experience with the first two tumuli. The primary modification was the inclusion of a surface-water collection and monitoring system. Each pad has a drainage system beneath it to direct surface water to a monitoring station, where the water is either held for treatment or released if it meets discharge requirements.

Currently, two pads are full, a third is operational, and three others are being built. Each measures 50 by $90 \mathrm{ft}(15.25$ by $27.45 \mathrm{~m})$ and is capable of holding about 330 vaults. Contents are limited to contact-handled LLW (Fig. 11).

\section{Public Involvement}

Several major environmental cleanup decisions were reached in 1995 with stakeholders playing key roles. DOE's public involvement program continued to hold regular stakeholder meetings in which citizens were updated on environmental management work on the reservation. DOE also hosts numerous other workshops and public meetings (Fig. 12). In addition, the Oak Ridge Reservation Environmental Management Site-Specific Advisory Board was formed and began operation in late 1995. 


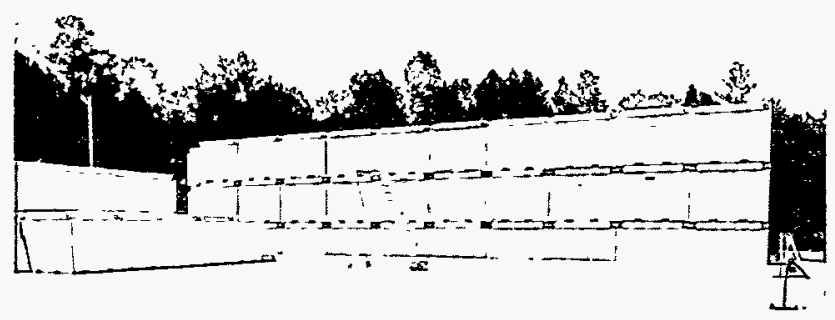

Other 1995 public-involvement activities include the following:

- three environmental management stakeholder meetings,

- several meetings on a proposal to privatize treatment of Oak Ridge's mixed waste,

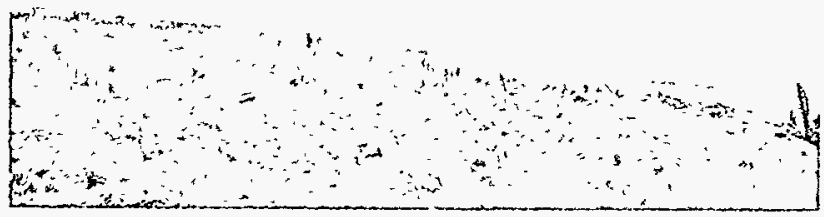

Fig. 11. Waste vaults are stacked on reinforced concrete pads at ORNL's Interim Waste Management Facility

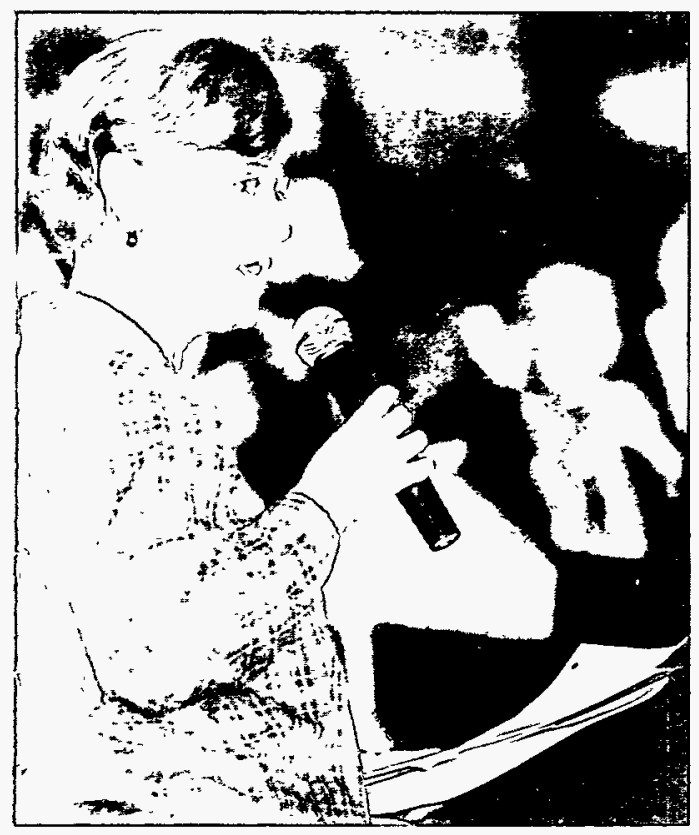

Fig. 12. A concerned citizen comments on the plan proposed for the cleanup of the Lower East Fork Poplar Creek floodplain.
- a workshop to gather input on cleaning up contaminated ponds at ORNL,

- a public comment period on the Chestnut Ridge Filled Coal Ash Pond Proposed Plan,

- a public workshop on the Baseline Environmental Management Report,

- a public workshop on the Molten Salt Reactor Experiment remedial action program at ORNL,

- a video conference on the Draft Waste Management Programmatic Environmental Impact Statement, and

- a meeting with members of the Merriwater Homepark Association concern testing of groundwater in their neighborhood.

\section{EnvironMENTAL Fair 1995}

DOE held its fourth annual EnvironMENTAL Fair on Tuesday, October 10. More than 2000 sixth-graders from 27 area schools had fun while learning what we can all do to make the world a cleaner place (Fig. 13).

\section{Common Ground Process Concludes}

A process that began in 1994 to involve all affected stakeholders in

land-use planning at the ORR concluded in late 1995. More than 350 stakeholders participated in the Common Ground Process, including citizens who live and work in the surrounding region, local government and union leaders, opinion leaders and regulators, and senior management from DOE and Energy Systems.

Conclusions reached in the final Common Ground report will be used to aid in reaching cleanup decisions and in strategic planning for overall land use. The overall vision specifies that the site should serve as an integrated science, education, and technology complex operated in partnership with the private sector. Under this scenario, the 


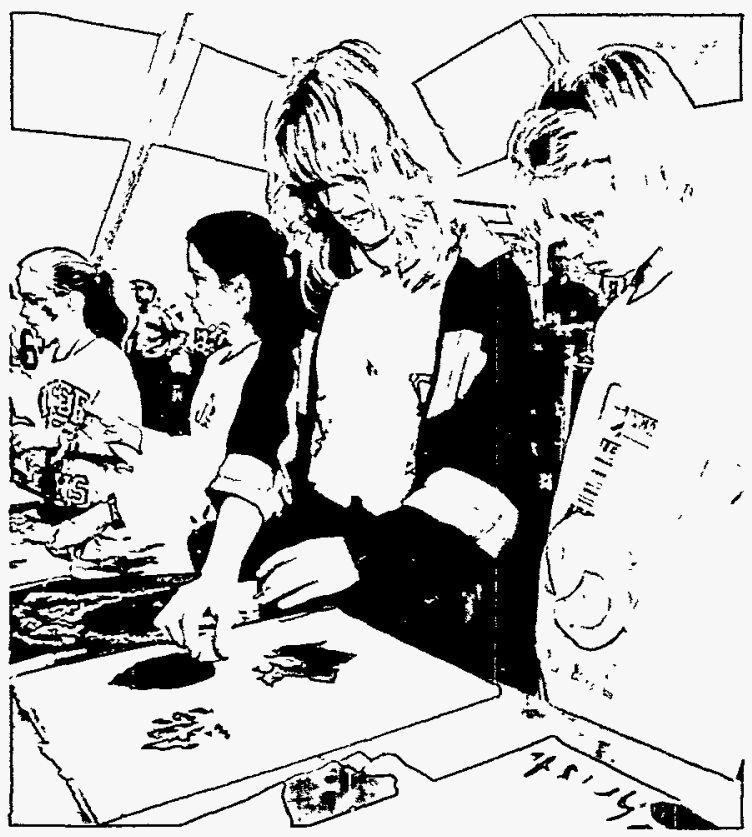

Fig. 13. Students at the EnvironMENTAL Fair are introduced to "the World of Leaves."

reservation would be managed by the federal government as a single parcel. The final report also recommends a comprehensive planning process, led by a group of federal, state, and local interests, to work through land-use decisions.

\section{Site-Specific Advisory Board Convenes}

In September 1995, the Oak Ridge Environmental Management Site-Specific Advisory Board held its first meeting. The board was established to advise the agency on environmental management issues, including recommendations for cleanup levels, technology development, and long-term waste management issues. The group includes 17 citizen members from communities affected by cleanup decisions and three nonvoting members from DOE, TDEC, and EPA Region 4. The board co-hosted with DOE two workshops on DOE's Prioritization List for Fiscal Year 1998.

\section{Resources Available to the Public}

You can get the latest information on environmental cleanup and waste management in Oak Ridge, including the Public Involvement Calendar, at the following web addresses:

http://www.doe.gov reaches the national DOE web site;

http://www.em.doe.gov takes you to the national DOE Environmental Management web site;

http://www.ornl.gov provides access to all ORNL home pages, plus home pages for the Y-12 Plant, the K-25 Site, ORAU, Energy Systems, and other sites of local interest; and

http://www.ornl.gov/doe_oro reaches the DOE Oak Ridge Operations web site.

Stakeholders may also obtain information from the following sources:

- Environmental Management Community Relations Office, 1-800-382-6938;

- Lockheed Martin Energy Systems, Community Relations Program, 1-800-382-6938 (574-8093 in Oak Ridge);

- The Information Resource Center, 105 Broadway Avenue, Oak Ridge, TN 37830, (423) 241-4582;

- DOE Oak Ridge Public Information Office, P.O. Box 2001, Oak Ridge, TN 37831-8502, (423) 576-0885; 
- Center for Environmental Management Information, 1-800-736-3282 (1-800-7EMDATA) (a publication clearinghouse serving the public, educators, and industry); and

- Environmental Management Advisory Board Information Line, 1-800-862-8860, Washington, D.C. (provides information on meeting dates, locations, and topics for the national advisory board).

\section{WE STUDY THE EFFECTS OF RADIATION AND CHEMICALS}

Activities on the ORR involve handling radioactive materials, operating radiationproducing equipment, and working with chemicals known to be harmful to people and the environment. Radiological and chemical "dose" assessments evaluate the possible exposure of public to radioactive elements and harmful chemicals as a result of routine operations on the ORR (Fig. 14). We assess and record compliance with regulations for protection of people and the environment. Thousands of samples of air, soil, and water are analyzed each year. The results are used to determine the amount of exposure that a hypothetical, "maximally exposed" individual could receive during the year as a result of operations on the ORR.

\section{What Do We Mean by Risk?}

When we estimate the risk associated with activities on the reservation, we are calculating the odds of activities on the reservation affecting the health of the local population. These calculations are based on known effects that chemicals and radiation have on the human body. All of the sampling and analysis compiled in the ORR annual site environmental report culminate in the calculation of "dose" of radiation and chemicals to the public (if any) that can be attributed to the activities on the reservation. For example, the maximum possibie radiological effective dose equivalent (EDE) attributed primarily to

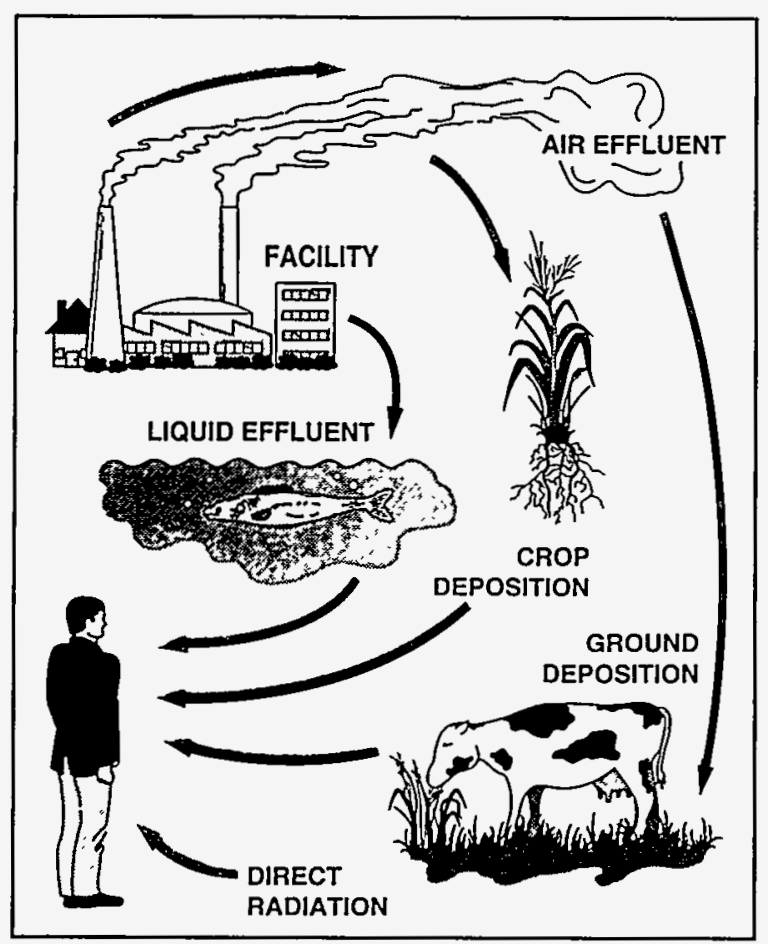

Fig. 14. Chemical and radiation pathways. We can receive internal or external exposure to chemicals, radioactive materials, and radiation by way of a number of pathways. We receive radiation directly from cosmic radiation and from particles embedded in soil and suspended in air and water. We can breathe air or drink water that have both chemical and radiological airborne contaminants suspended in them. In addition, airborne contaminants that settle on grass in pastures and hayfields can be eaten by cows, and the contaminants can show up in the milk we drink. Similarly, contaminants can be retained in honey, fish, and game animals. 
the air and water pathways, eating deer, and direct radiation exposure was calculated in 1995 to be 6 mrem.

\section{WE MONITOR THE ENVIRONMENT}

The ORR environmental monitoring program has two components: effluent monitoring and environmental surveillance, both of which are intended to demonstrate that reservation operations comply with DOE criteria as well as other applicable federal, state, and local standards and requirements.

- Effluent monitoring involves sampling known air and water discharge points to determine the amount of radioactive and chemical contaminants (if any) contained in the released material.

- Environmental surveillance includes sampling the air, water, and biological material to detect any radioactive or chemical contaminants that may be attributable to activities on the reservation.

Information from these programs is then used to document compliance with applicable environmental laws and regulations and DOE requirements, identify trends, inform the public, and contribute to general environmental knowledge.

We monitor the local environment to acquire data so that we can make an assessment of our effect on the public and environment and, where practical, reduce and eliminate the release of radioactive and hazardous materials. Information gathered during specific monitoring programs is published in routine reports to local, state, and federal agencies and to the public. The environmental monitoring program assists in (1) fulfilling DOE's policy of protecting the public, employees, and the environment from harm that could be caused by its activities and (2) reducing negative environmental impacts to the greatest degree practical.

\section{Air}

We sample both effluent air and ambient air on the ORR. Effluent air flows from a source into the environment. Ambient air is the air that exists in the surrounding area. Both radiological and nonradiological air emissions from individual buildings and specific plant locations as well as locations in the surrounding communities are monitored. Air monitoring programs provide information to protect the health of plant workers and the general public, and to demonstrate compliance with state and federal air quality requirements (Fig. 15). Programs are revised through the years to meet revisions in state and federal requirements.

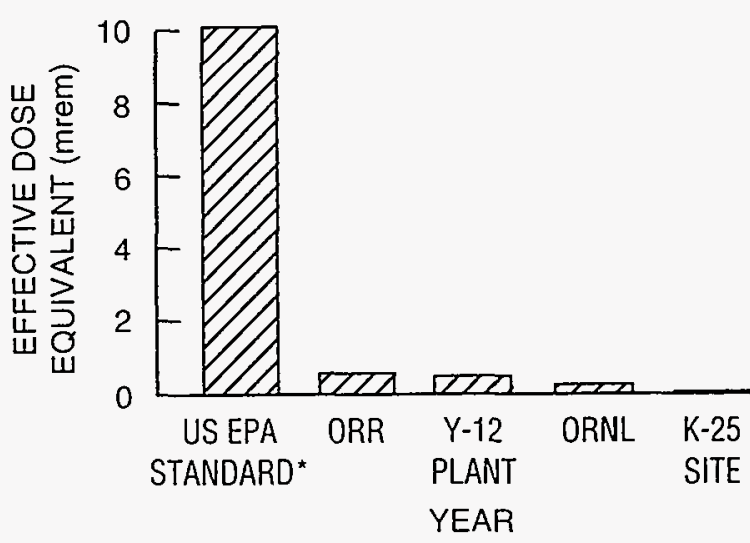

*National Emission Standards for Hazardous Air Pollutants (NESHAP)

Fig. 15. Total 1995 effective dose equivalents to maximally exposed individual from airborne releases. In comparison, local natural background radiation is about 300 mrem ( $3 \mathrm{mSv}$ ) per year. 
For all permitted air emission sources at the three facilities on the ORR, 1995 air emissions were lower than TDEC-permitted air emission limits. No noncompliances were noted by TDEC at any of the facilities during inspections of all permitted emission sources. Based on facility-specific and ORR nonradiological and radiological ambient air monitoring programs, ORR operations do not significantly affect local air quality.

The additional EDE received by a hypothetical maximally exposed individual from ORR emissions in 1995 was calculated to be $0.5 \mathrm{mrem}$, which is below the National Environmental Standards for Hazardous Air Pollutants (NESHAP) standard of $10 \mathrm{mrem}$, and well below the 300 mrem received from natural sources annually.

\section{Direct Radiation}

Direct radiation exposure rates are measured at a number of locations on and off the ORR to determine whether radioactive releases from the ORR are significantly increasing radiation levels above the normal background levels. External exposure rates from background sources in the state of Tennessee average about 6.4 microroentgens $(\mu \mathrm{R}) /$ hour and range from 2.9 to $11 \mu \mathrm{R} /$ hour. These exposure rates translate into annual EDE rates that average $42 \mathrm{mrem} /$ year and range from 19 to $72 \mathrm{mrem} /$ year (T. E. Myrick et al. 1981, State Background Radiation Levels: Results of Measurements Taken During 1975-1979, ORNL/TM-7343, Oak Ridge, Tenn.)

The average exposure rate at perimeter air monitoring stations around the ORR during 1995 was about $7.8 \mu \mathrm{R} /$ hour $(51 \mathrm{mrem} /$ year). Almost all measured exposure rates beyond the ORR boundaries are near background levels, except for two locations: Poplar Creek on the ORR and a 1.7-km (1.1-mile) section of the Clinch River.

The radiation field along Poplar Creek emanates from storage areas within the K-25 Site. Anglers have been observed on the section of the creek affected by this area. Exposure-rate measurements (corrected for background) taken along the creek during 1995 ranged between 3.9 and $8.3 \mu \mathrm{R} /$ hour, which is equivalent to an EDE rate of 0.003 to $0.006 \mathrm{mrem} / \mathrm{hour}(0.00003$ to $0.00006 \mathrm{mSv} / \mathrm{hour})$. Actual fishing activity on the affected stretch of Poplar Creek needs to be determined. A 4-hour fishing trip could have resulted in an EDE between 0.01 and $0.02 \mathrm{mrem}(0.0001$ to $0.0002 \mathrm{mSv})$. In the extremely unlikely event that someone would fish this stretch of Poplar Creek for 250 hours per year, that person would receive an EDE of about 1 mrem $(0.01 \mathrm{mSv})$.

Exposure from the area on the Clinch River has been attributed to radiation from experimental plots containing cesium-137. Exposure rates measured in 1987 averaged $13 \mu \mathrm{R} /$ hour and ranged between 3.5 and $18 \mu \mathrm{R} /$ hour. The site has since been remediated, but it has not yet been surveyed. For that reason, the exposure rate during 1995 was assumed to be the same as the rate during 1994 and $1993,8 \mu \mathrm{R} /$ hour (equivalent to $0.006 \mathrm{mrem} /$ hour). Hypothetically, if someone spent 250 hours during 1995 fishing at either location, he or she could have received an EDE of about $1 \mathrm{mrem}$.

\section{Water}

\section{Suriace Water}

The federal Clean Water Act allowed the EPA to establish the National Pollutant Discharge Elimination System (NPDES). NPDES provides limits for effluents discharged into the surface water. On the ORR, 438 water locations are sampled at various frequencies during the year (from once every five minutes to once per year) for NPDES compliance 
monitoring. About 63,000 water analyses or measurements were completed. Thirty-six NPDES noncompliances with permit requirements were found among these measurements and field observations. Nearly half of these were for suspended solids in stormwater runoff. The compliance rate for 1995 was greater than $99 \%$.

In addition to the NPDES program, surface water from 22 locations around the ORR is analyzed to compare with surface water reference value; to compare with DOE derived concentration guides (DCGs); to describe background water quality; to evaluate potential contaminant releases; and to comply with monitoring requirements of regulations, permits, and agreements. Water quality testing programs look for 79 elements, industrial chemicals, radioactive components, inorganic elements, and organic compounds. Hundreds of discharge points, storm sewers, and local streams and rivers

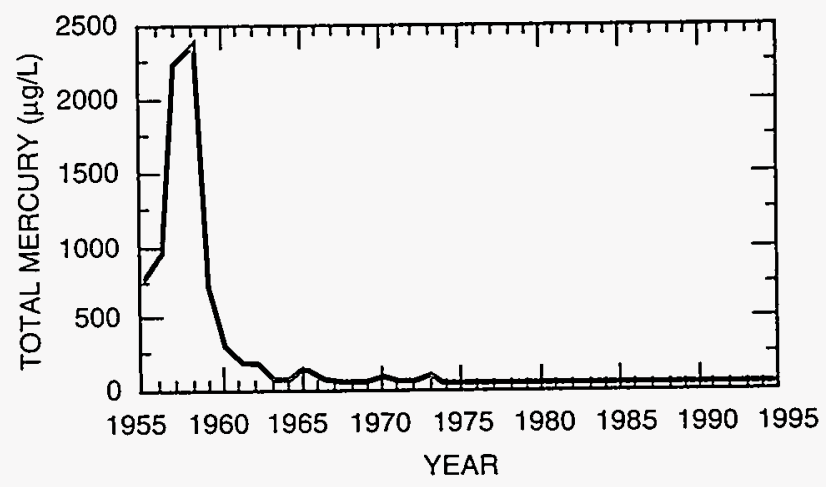

Fig. 16. Mercury concentrations in surface water leaving the $\mathrm{V}-12$ Plant, 1955-1995. Although most of the mercury was discharged during the 1960s and 70 s, its legacy remains downstream, in East Fork Poplar Creek. are monitored on and around the ORR (Fig. 16).

Samples were collected from 22 locations around the ORR and were analyzed for 79 parameters. Of these, the only parameters that exceeded the Applied Tennessee Water Criteria were chromium at White Oak Dam, arsenic at the water supply intake for Knox County, and arsenic and mercury at Melton Hill Reservoir at the Oak Ridge Marina.

Averaged annual concentrations of radionuclides in water samples at the K-25 Site (Gallaher) Water Plant and at the Kingston Municipal Water Plant were used to calculate potential individual EDEs for drinking water. A worker who drank $365 \mathrm{~L}$ (half of the worker's total annual intake) of K-25 Site water during 1995 could have received an EDE of about 0.1 mrem; a person who drank a greater amount of Kingston water $(730 \mathrm{~L})$ could have received an EDE of about 0.15 mrem.

The maximum annual EDE associated with water exposure routes other than drinking water or eating fish was calculated to be $0.4 \mathrm{mrem}$, which is attributed to shoreline use. Doses from boating or swimming in the Clinch River are negligibly small.

\section{Groundwater}

Local groundwater provides some domestic, municipal, farm, irrigation, and industrial uses, but most of the population in the Oak Ridge area does not rely on groundwater for potable water supplies. However, because it is available, the local groundwater must be viewed as both a potential pathway for exposure to hazardous wastes and as a means for contaminant transport (Fig. 17).

We are able to evaluate the impact of ORR activities on local groundwater and to limit any activities that have an adverse effect on the groundwater by sampling. Major federal regulations specify actions to be followed in the groundwater monitoring program. Groundwater is monitored for radioactive elements, organic compounds that evaporate easily, (volatile organic compounds), trace metals, and major ions (electrically charged atoms and molecules). 


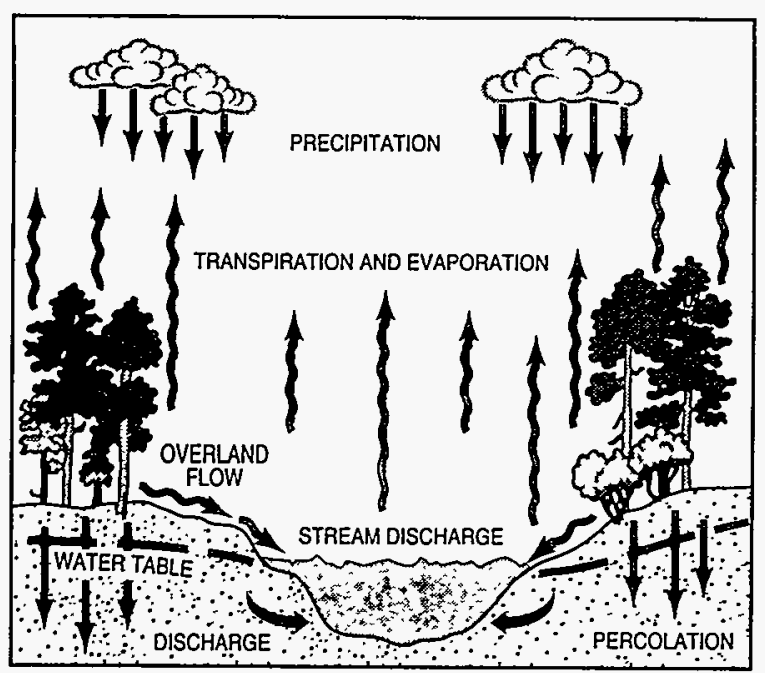

Fig. 17 Groundwater is precipitation that has percolated into subsurface rock and soil. The water table, the depth to which the ground is saturated with water, varies seasonally with the precipitation rate. Groundwater moves through the ground and discharges to bodies of surface water where the two meet. Because groundwater can transport both chemical and radiological pollutants from underground waste-burial sites, both surface water and groundwater are sampled on and off the reservation to determine the presence, amount, and movement of wastes.

The numerous wells on the ORR provide for surveillance of groundwater quality. Additional characterization is being conducted in the Environmental Restoration Program. Radiological groundwater monitoring is conducted for specific radionuclides and for general levels of radioactivity.

Plant perimeter groundwater monitoring stations are used to assess potential migration of contaminants beyond the boundary of the ORR. Groundwater data collected from these stations during 1995 indicate that only a few locations at the Y-12 Plant and ORNL show any evidence of contamination. At the Y-12 Plant, results from several recently completed wells and a group of off-site U.S. Geological Survey wells indicate that groundwater contaminated with volatile organic compounds is migrating eastward across Scarboro Road and into Union Valley. There are no users of groundwater in the affected area. Results from the off-site spring and residential well monitoring program indicate no evidence of contamination at these locations during 1995.

\section{Other Media}

Several other media are sampled and analyzed to evaluate the impact of the ORR on its surroundings and to comply with federal and state regulations. These media include soil, sediment, hay, vegetables, (lettuce, turnips, and tomatoes), milk, fish, and resident wildlife (white-tailed deer and Canada geese). Samples are analyzed for radioactive elements as well as for chemicals of interest (such as fluorides in hay and PCBs in fish, for example). Samples are taken locally, both from the ORR and from surrounding communities.

\section{Soil}

Soil is sampled to determine whether airborne radionuclides are accumulating in the soil. Soil samples are taken annually at nine locations on the reservation. Detected radionuclides and levels of radioactivity in 1995 samples were similar to 1994 levels and were all within acceptable ranges. 


\section{Sediment}

No regulatory requirements apply to stream or lake sediments; however, sediments can act as a record of water quality by storing and concentrating certain contaminants. For that reason, annual sediment sampling was begun on the ORR in 1993. Sediment samples collected from 16 locations on and around the reservation are analyzed for certain radionuclides, metals, chlorinated pesticides, PCBs, and hazardous organic compounds. Three years' worth of data indicate that these sediments are reflective of processes nearby or upstream of the sampling location.

\section{Hay}

Hay from the ORR is sold to area farmers. Six locations from which hay is cut have been identified as areas where airborne materials could be deposited from ORR sources. A reference site has been added to the sampling locations. The hay was collected and composited into three samples, which were analyzed for fluoride, tritium, beryllium-7, potassium- 40 , cobalt- 60 , iodine- 129 , and cesium-137. These analyses show that essentially all of the dose from consuming beef and milk from cattle that had eaten the hay would have come from naturally occurring potassium-40. The EDE from eating beef and drinking milk from cattle that ate this hay in 1994 was estimated to be about 20 mrem; if potassium-40 (a naturally occurring isotope) were excluded, the EDE would be $0.001 \mathrm{mrem}$.

\section{Vegetables}

Tomatoes, lettuce, and turnips were grown in soil plots on the ORR. The vegetables were analyzed for radionuclides. The maximum individual EDE from eating all three vegetable types in 1995 was estimated to be about 5.3 mrem. If potassium-40, a naturally occurring isotope, is excluded, the maximum EDE would be about $0.05 \mathrm{mrem}$.

Milk

Milk is a potentially significant exposure pathway of some airborne radionuclides such as iodine and strontium, which can be deposited on pasture grass, and thus consumed by dairy cows.

Potential dose from milk ingestion was evaluated using concentrations of strontium and iodine measured in milk collected from nearby farms. An individual was assumed to drink 310 liters of milk containing the highest measured quantity of total strontium. Such an individual could have received an EDE of about $0.1 \mathrm{mrem}$. No iodine or tritium was detected in milk samples during 1995.

\section{Honey}

Three bee colonies are located on the ORR. The honey produced in these hives was sampled, and the sampling results were used to give an indication of potential EDEs to persons who eat honey produced by bees that may have collected pollen on the ORR. If an adult consumed $1 \mathrm{~kg}(2.2 \mathrm{lb})$ of the sampled honey during the year, the resulting EDE could be about 0.09 mrem. The average adult likely consumes less than $1 \mathrm{~kg}$ of honey per year. 


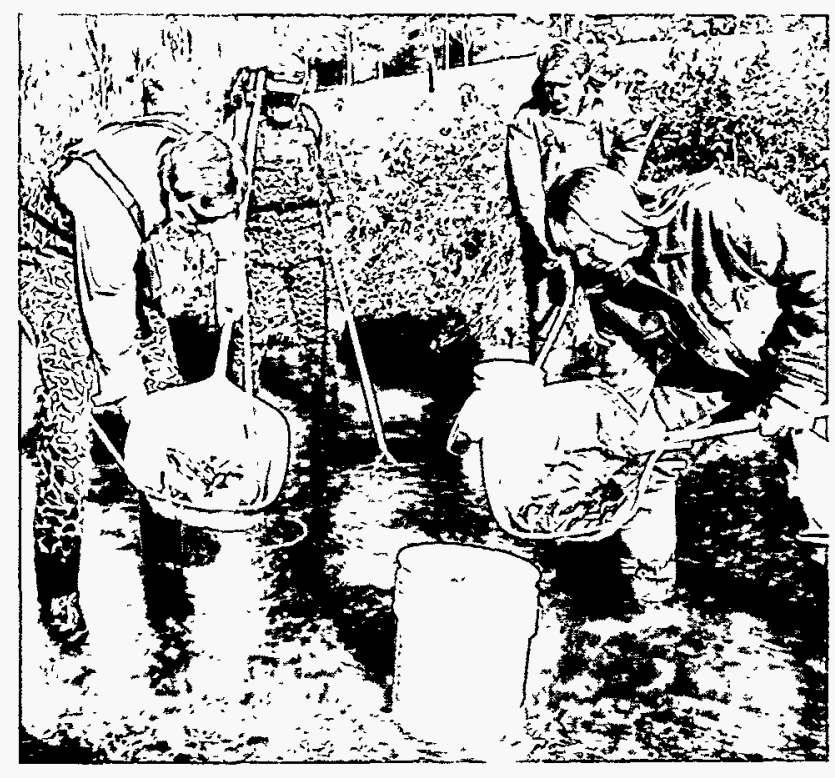

Fig. 18. Fish are routinely sampled from local streams. Fish are collected for population studies as well as for chemical and radiological analyses.

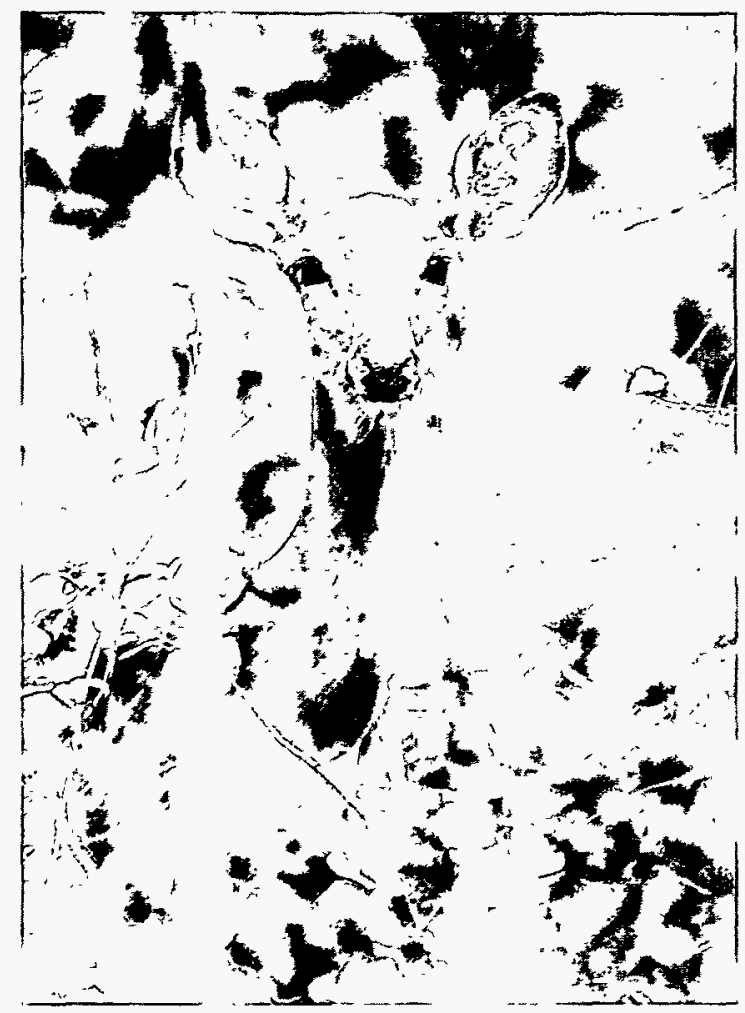

Fig. 19. White-tailed deer are a common sight on the reservation.

\section{Fish}

Members of the public potentially could be exposed to contaminants originating from DOE activities through consumption of fish caught in area waters. This exposure pathway is monitored by annually collecting and analyzing fish from six river locations (Fig. 18). Sampling sites are located upstream and downstream of DOE activities and at one off-site (background) location. In 1995, most parameters analyzed for in both sunfish and catfish were undetected. For PCBs, reported values for sunfish and catfish were below the federal Food and Drug Administration (FDA) tolerance of 2 parts per million; for mercury, all reported values were below the FDA action level of 1 part per million. Radiation doses that would result from eating fish ranged from 0.2 to $1.1 \mathrm{mrem} /$ year.

\section{White-Tailed Deer}

The eleventh annual deer hunts managed by DOE and the Tennessee Wildlife Resources Agency were held on the ORR during the final quarter of 1995 (Fig. 19). From the total harvest of 489 animals, $295(60.3 \%)$ were bucks and 194 (39.7\%) were does. The heaviest buck had nine antler points and weighed $176 \mathrm{lb}$. The greatest number of points (13) was found on a buck weighing $147 \mathrm{lb}$. The heaviest doe weighted $121 \mathrm{lb}$. The average $\mathrm{EDE}$ for an individual consuming an average-sized deer (89 lb) from the ORR in 1995 having a cesium-137 concentration of $0.18 \mathrm{pCi} / \mathrm{g}$ and a strontium-90 concentration in tissue (based on 1994 data) of $0.96 \mathrm{pCi} / \mathrm{g}$ would be about 3 mrem. Given the average concentration of cesium-137, the

collective EDE from eating all harvested deer in 1995 was estimated at about 0.09 person-rem. 
Of the 489 deer harvested, 8 were confiscated because they exceeded established release limits $\left(5 \mathrm{pCi} / \mathrm{g}\right.$ for ${ }^{137} \mathrm{Cs}$ and/or $20 \mathrm{pCi} / \mathrm{g}$ for $\left.{ }^{90} \mathrm{Sr}\right)$. Concentrations of ${ }^{90} \mathrm{Sr}$ in bone exceeded the confiscation limit in all eight confiscated deer. The deer confiscated during the 1995 hunt represent $1.6 \%$ of the total deer harvested.

\section{Canada Geese}

One objective of the ORR waterfowl program is to determine concentrations of gamma-emitting radionuclides accumulated by waterfowl that frequent waste disposal areas. The sampling areas are chosen because Canada geese congregate there (Fig. 20). Geese are highly mobile animals that range freely between sites on and off the reservation. For that reason, the results in this report should be taken as an indication of the possible overall impact that the reservation has on the geese rather than as an evaluation of the collection sites.

The annual roundup of Canada geese took place on June 28,29 , and

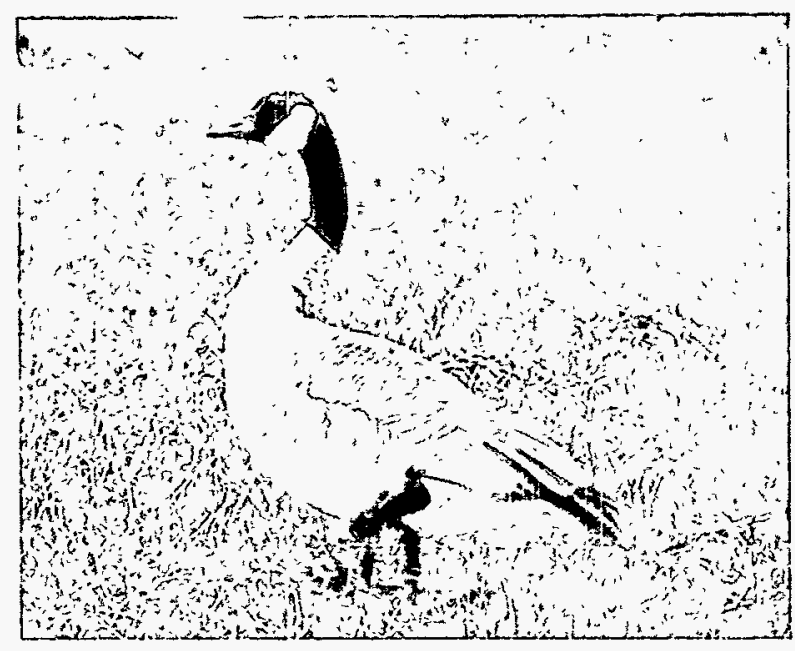

Fig. 20. Many Canada geese found on the reservation are year-round residents of the local area. Some, like this one, are tagged and studied. 30, 1995. During the roundup, whole-body gamma scans were conducted on 86 geese at the deer-checking station: 10 from ORNL, 20 each from the K-25 Site and Melton Hill Dam, 21 from the Oak Ridge Marina, and 15 from the Y-12 Plant.

The average cesium-137 concentration was estimated to be $0.084 \mathrm{pCi} / \mathrm{g}$. The maximum cesium-137 concentration $(2.1 \mathrm{pCi} / \mathrm{g})$ was detected in a goose collected at the $\mathrm{K}-25$ Site. A person eating a Canada goose containing the maximum 1995 concentration of cesium-137 would receive an EDE of about $0.03 \mathrm{mrem}$. The 1995 collective EDE from consumption of harvested geese that may have spent time on the ORR would be about 0.0019 person-rem.

\section{Eastern Wild Turkey}

Twelve live eastern wild turkeys were collected on the ORR during February 1995. These turkeys were whole-body counted at the deer counting station and released in an off-site wildlife management area. Cesium-137 was detected in 1 of the 12 turkeys that were counted. The estimated ${ }^{137} \mathrm{Cs}$ concentration was $0.09 \mathrm{pCi} / \mathrm{g}(0.0033 \mathrm{~Bq} / \mathrm{g})$. The average weight of a male wild turkey is about $24 \mathrm{lb}(10.9 \mathrm{~kg})$ and the female wild turkey weights about $12 \mathrm{lb}(5.4 \mathrm{~kg})$. If a turkey [average weight $18 \mathrm{lb}(8.16 \mathrm{~kg})$ ] was consumed by one individual and the edible portion was $4.08 \mathrm{~kg}(9 \mathrm{lb})(50 \%$ of the total weight of the turkey), the estimated EDE would be about $0.01 \mathrm{mrem}(1 \mathrm{E}-4 \mathrm{mSv})$. Two turkeys are the bag limit in a wildlife management area per season. If one individual consumed two birds collected from a wildlife management area at the aforementioned ${ }^{137} \mathrm{Cs}$ concentration, the estimated EDE wold be about $0.02 \mathrm{mrem}(2 \mathrm{E}-4 \mathrm{mSv})$. 


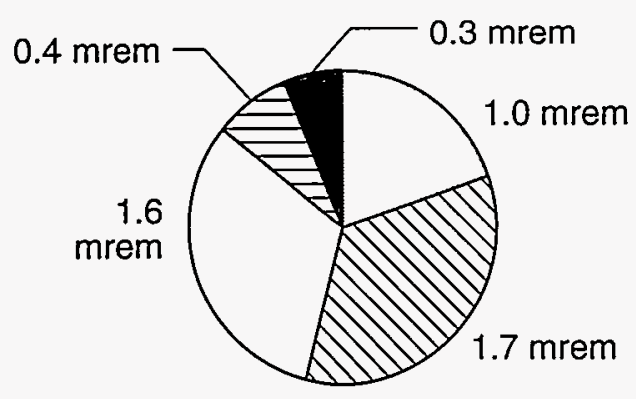

SIV ATMOSPHERIC EMISSIONS

DRINKING WATER

EATING FISH

ए OTHER ACTIVITIES

$\square$ DIRECT RADIATION

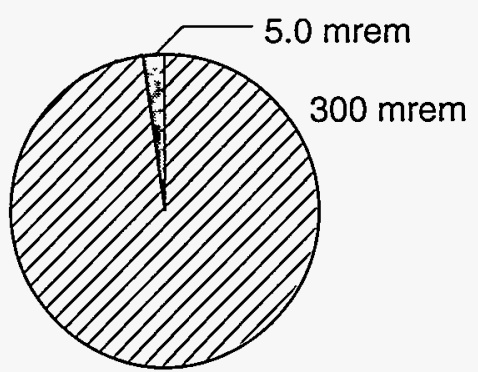

W TOTAL MAXIMUM EDE

DTD BACKGROUND

Fig. 21. A comparison of maximum EDEs via various exposure pathways.

\section{SO ... WHAT DOES IT ALL MEAN?}

Environmental monitoring and surveillance are necessary to determine the effect that the ORR has in it neighbors. The relative contribution of the air, water, and direct radiation exposure routes on the maximum individual EDE from ORR operations is shown in Fig. 21. In many cases the maximum EDEs are calculated using conservative assumptions. Even so, the annual EDE of about 6 mrem (sum of EDEs attributed to these exposure routes) is considerably less than the annual dose from background ( $300 \mathrm{mrem}$ ). As shown in Fig. 21, the sum of the maximum EDEs for 1995 is about $2 \%$ of the average background radiation dose for the Oak Ridge area.

Our mission is changing from working solely for the national defense to working on environmental restoration, waste management, decontamination and decommissioning, and technology transfer projects. Everyone who works on the ORR remains committed to working safely with regard to each other, the public, and the environment. This goal will be accomplished by keeping emissions as low as reasonably achievable, enhancing the strict safety controls that are already in place, and using state-of-the-art technology to complete environmental remediation projects in the most cost-effective and efficient manner possible. Although our mission is changing, our new tasks remain essential as the nation moves forward to restore and preserve the environment for future generations. 


\section{Photographs and Figures}

Cover photo

ORNL PHOTO 3638-96 (taken by Steve Eberhardt, Information Management Services)

1.

ORNL DWG 93M-6313R

2.

ORNL PHOTO 2623-94

3.

ORNL PHOTO 2622-94

4.

ORNL PHOTO 2624-94

5.

ORNL PHOTO 2220-96

6.

ORNL PHOTO 5739-95

7.

Y-12 PHOTO 318023

8.

ORNL DWG 96M-4861

9.

ORNL DWG 96M-4862

10.

K/PH 95-1846

11.

12.

ORNL PHOTO 4239-93

K/PH 95-3000

13.

ORNL PHOTO 3572-96

14.

15.

ORNL DWG 94M-5235R3

16.

17.

18.

19.

ORNL DWG 95M-8097R

ORNL DWG 93M-9236R2

ORNL DWG 95M-8354

ORNL PHOTO 10366-88

ORNL PHOTO 6792-95 (taken by Steve Eberhardt, Information Management Services)

20. ORNL PHOTO 1569-90

21. ORNL DWG 94M-11869R2 


\section{Definitions}

\section{- Radiological definitions}

- Radioactive material contains unstable atoms (isotopes) that become stable by emitting electromagnetic radiation and high-energy particles.

- Disintegration is the event in radioactive material that releases radiation, usually given as a rate; e.g., disintegrations per second (dps).

- Becquerel $(B q)$ is a unit of measure representing the amount of a radioactive material that undergoes 1 dps.

- Curie (Ci) the amount of a substance that undergoes $3.7 \times 10^{10} \mathrm{dps}\left(1 \mathrm{Ci}=3.7 \times 10^{10} \mathrm{~Bq}\right)$.

- Gray $(G y)$ is a unit of measure for the energy imparted by ionizing radiation; $1 \mathrm{~Gy}=1$ joule per kilogram.

- Rad is a unit of measure for the energy imparted by ionizing radiation; $1 \mathrm{rad}=0.01$ joule per kilogram (1 rad $=0.01 \mathrm{~Gy}$ ).

- Roentgen $(R)$ is a unit of measure for the energy imparted to air by $X$ rays or gamma $(\gamma)$ radiation; $1 \mathrm{R}=2.58 \times 10^{-4}$ couloumbs per kilogram of air.

- Rem (roentgen equivalent man) is a unit of measure specific to human tissue; equivalent to the damage caused by one $R$ of $X$ rays ( 1 rem $=0.01$ Sieverts).

- Sievert (SV) is a unit of measure representing the radiation dose at $1 \mathrm{~cm}$ from a milligram of radium encased in a platinum container having $0.5-\mathrm{mm}$-thick walls; equivalent to about $8.38 \mathrm{R}$.

- Dose is an estimate of the amount of radiation that a body has received (in units of rads or grays).

- Dose equivalent is an estimate of damage to a specific organ based on the radiation it has absorbed (in units of rem or sieverts).

- Effective dose equivalent (EDE) relates the dose equivalents to the risk to the whole body (in units of millirem or millisieverts).

\section{- Chemical definitions}

- Chronic reference dose is the estimate of the amount of a chemical to which a human body is exposed daily that is likely to be without an appreciable risk of deleterious effects during a lifetime.

- Toxicity refers to the adverse effects, ranging from mild irritation to death, that a chemical can have on human health.

- Carcinogens are a class of chemicals that cause or increase the incidence of malignant neoplasms or cancers.

Fractions and multiples of units

\begin{tabular}{clllc}
\hline Multiple & Decimal equivalent & Prefix & Symbol & Report format \\
\hline $10^{12}$ & $1,000,000,000,000$ & tera & $\mathrm{T}$ & $\mathrm{E}+12$ \\
$10^{6}$ & $1,000,000$ & mega- & $\mathrm{M}$ & $\mathrm{E}+06$ \\
$10^{3}$ & 1,000 & kilo- & $\mathrm{k}$ & $\mathrm{E}+03$ \\
$10^{2}$ & 100 & hecto- & $\mathrm{h}$ & $\mathrm{E}+02$ \\
10 & 10 & deka- & $\mathrm{da}$ & $\mathrm{E}+01$ \\
$10^{-1}$ & 0.1 & deci- & $\mathrm{d}$ & $\mathrm{E}-01$ \\
$10^{-2}$ & 0.01 & centi- & $\mathrm{c}$ & $\mathrm{E}-02$ \\
$10^{-3}$ & 0.001 & milli- & $\mathrm{m}$ & $\mathrm{E}-03$ \\
$10^{-6}$ & 0.000001 & micro- & $\mu$ & $\mathrm{E}-06$ \\
$10^{-9}$ & 0.000000001 & nano- & $\mathrm{n}$ & $\mathrm{E}-09$ \\
$10^{-12}$ & 0.000000000001 & pico- & $\mathrm{p}$ & $\mathrm{E}-12$ \\
\hline
\end{tabular}

